\title{
The Making of Political Rituals in Albanian Society
}

\section{PhD Candidate, Lulzim Hoxha}

\author{
Lecturer at the "European University of Tirana" \\ Rr. Thoma kacorri, Vila nr.1, Postal Code 1023 \\ +355689037762, Iulzimhoxha_uet@yahoo.com
}

Doi:10.5901/ajis.2013.v2n8p179

\begin{abstract}
Society is often treated as a passive structure where are superposed all the ensembles of behaviours and cultures through the ideological, religious and legal rituals. Usually, researchers have the tendency of focusing mostly on the descriptions of sociocultural phenomenons of a society, leaving asside the way in wich these rituals reach the consensus or the resistance of the social group where are distributed. Whatever religion, culture, law or ideology to be constructed must invent several rituals which should conform to the social structures of society. Before the ideology is constituted, the social rituals should be recognized as such by the members of society, who give to these rituals a specific shape that makes sense to them. Therefore, we can say that the constituation of a given ideology, religion, law or ideology depends not only on the will of the leader who has in control it's modes of production, but also in the interaction between the ideology itself and the way in wich it is translated on the modes of comprehension of society. In this work l'll try to explain how the religious worships during the Ottoman Empire are transformed and adapted as politico-ideological in Enver Hoxha's Despotistic regime in Albania. This will be realized by concentrating on the idea that ideological and social rituals in general, to exist they should firstly be recognized as such by the members of society in which these rituals will be routinized.
\end{abstract}

\section{Introduction}

In this work l'll try to explain how the religious worships during the Ottoman Empire are transformed and adapted as politico-ideological in Enver Hoxha's Despotistic regime in Albania. This will be realized by concentrating on the idea that ideological and social rituals in general, to exist they should firstly be recognized as such by the members of society in which these rituals will be routinized. This hypothesis will be argued by Karl Wittfogel's theory of "Oriental Despotism" and Max Weber's concept of sultanistic regimes.

It's clear that after almost five centuries under conquest, some of the Ottoman social rituals would still remain inside the Albanian culture, although in a modified way. Above all, culture is constructed after a long process of interaction with foreign neighbour cultures. In this context, the religious rituals of the Ottoman invadors would be modified in different forms of social practices during Albania's despotistic regime. In 1967 the Albanian Labor Party decided the total abolition of religion with all it's monuments and rituals, wich were all substituted by Enver Hoxha's glorification and all the social rituals that inspired his personality cult.

Through this approach we'll be more clear about the social basis of Albanian Despotism, but also the way in wich social and religious rituals are manipulated and used as social practices for the birth of personality cult.

\section{The great symbol of total submission}

Under the conquest of The Ottoman Empire Albanian christians were subject to extremely harsh rules: They were forced to unpaid work (Drudgery) by turkish feudal lords; to pay a high amount of rent and taxes; to send their male children in the janissary troops of the turkish army etc. But these material constrains were completed by further symbolic rules. One of these type of constrains was the order according whom "Every christian who encounters a muslim in his way, is obliged to descend off his horse immediately."

The importance of this order is purely symbolic, in the way of maintaining an established level of hierarchy between

${ }^{1}$ Thëngjilli P, Renta Feudale dhe Evoluimi i saj në Vise Shqiptare (Shek. XVII - mesi i shek. XVIII), Shtëpia Botuese e Librit Universitar, Tiranë 1990, p.34 
the social groups. This act of submission is roughly similar to that of the bow of the sunnis towards allah. Therefore, it could be said that here we have to do with two different religious groups with one thing in common: the gesture of total submission towards the Big Other (in Lacanian terms).

According to Johannes Ostrup "The culture teaches people to obey unconditionaly when the despotic authority demands it. It also teaches them to perform gestures of reverence, where more than the act of submission what is really needed is the symbol. In fact, every culture has different ways to show respect; and as a matter of fact there are many ways to express submission. But no other symbol does expres total submission as much as the gesture of bow down (perkulja ne shenje respekti)."2 As Wittfogel puts it in his most known book Oriental Despotism "The inferior man, aware that the anger of the superior force (wether it material or spiritual) can punish him, prefers to assure his benevolence (dashamirësi) by humiliating himself." 3 As we see, the identity of the member of a social group is defined by it's position in front of the other, wich also uses this ritual towards the sultan and also to allah. Nonetheless, the gesture of bowing down is not only used by the sunnis towards god, but as Wittfogel reminds us "Under the Oriental Despotism the bow down is a prevailing form of greeting the ruler or other persons of recognized authority" (Wittfogel: 151). However it should be emphasized that generally "the bow down is characteristic of Oriental societies while it isn't present in higher agricultural civilisations of classical antiquity and European middle ages" (Wittfogel: 152). Meanwhile in the Ottoman Turkey this practice remained till the end of the sultanate, and here Ostrup also includes "the kissing of feet as another sign of total submission towards the supreme lord" (Ostrup: 105).

In the symbolic act of submission we find a common tendency on raising the personality of the sultan, from a political to a divine figure. In other words, the way in wich is perceived the political power of the sultan it also involves the religious power. The Albanian muslims in all the four vilayets were all subject to this symbolic and material submission wich puts the sultan at the center of their political and religious worship.

It would be appropriate to add that the Ottoman culture didn't have a great impact only in the islamisation of Albanian christians, but also in the humiliation of the christians who maintained their religion. The Islamic domination and the hard conditions of non-muslims were a huge challenge for the basic principles of christianity as a religion characterized by a more liberal tendence, with a "modern" god who sent his son down in the material world. Although these people didn't turn to islam, they were already forced to follow the religious rituals of Islam in a social way: They only substituted the bow with the descending off the horse. It appears this was the best way for the Ottoman authorities to maintain and propagate the same social rituals even for the non-muslims who could exercise their religious practices only by accepting these rituals of submission.

\section{Sultanism as a political outcome}

The concept of Sultanism was created by Max Weber in his famous book "Economy \& Society: an outline of interpretive sociology". He defines Sultanism as "an extreme form of patrimonialism"4. However, some decades later Linz and Stepan used the notion of sultanism to explain some particular forms of despotism wich characterize mainly the Oriental societies from Africa to South America, including the Romanian regime under the rule of Ceausesku. In their work "Problems of democratic transition and consolidation" Juan Linz and Alfred Stepan refering to Weber precise that, according to them, "he didn't use the notion of sultanism to explain the religious claims of obedience but only to explain the type of domination and rulership of a regime." ${ }^{5}$ However, it results that - as I explained previously - the ways of perception of the political regime and those of religion are deeply connected in the social structures of society. Above all, as Albert Doja remarks correctly "religion is viewed as a tradition wich is distributed through the social community"6 wich means that it has a crucial impact in the formation and conservation of the social edifice. Especially in Albanian society, religion and all it's ensemble of rituals "rather relies in the social culture" (Doja: 2008). Through the social practices mediated by the Islamic domination we can not only understand the social structures of Albanian society, but also we can comprehend all the ensemble of behaviours, understandings, modes of perception of this society after five centuries of invasion. To explain this, I think firstly it would be important to analyse the social intentions of religion in a given society.

\footnotetext{
2 Ostrup J, Orientalische Hoflichkeit, Leipzig: O. Harrassowitz 1929, p.72

3 Wittfogel K, Despotizmi Oriental, Botime Toena, Tiranë 2000, p. 150

4 Weber M, Economy \& Society: An Outline of Interpretive Sociology, Berkeley University of California Press, 1978, f.231

${ }^{5}$ Linz J \& Stepan A, Problems of democratic transition and consolidation, John Hopkins University Press, Baltimore, 1996, f.42

${ }^{6}$ Doja A, Bektashizmi në Shqipëri (Histori Politike e Një Lëvizjeje Fetare), AlIS, Tiranë 2008, p. 59
} 
Religion - ultimately just like as law, culture or ideology - has an important influence in giving some order to a social community. It's mission is to conserve an established order through several rituals, worship or modes of glorification wich also aim at particular social exchanges in form of social rituals. Hence, religion is not some kind of an isolated myth apart from the social reality, because it is formed only in the moment when it comes in contact with this social reality. For this reason religious rituals are above all social rituals, as the figure of the Sultan in the Ottoman Empire was at once political and religious. By understanding the social basis of the daily rituals we can be able to understand the behaviours of a given society after the changement of political systems. In this regard, Wittfogel emphasizes a general tendency in the political systems that were created after the great Oriental Empires were collapsed. According to him, "they are nothing more than small and separated reproductions of the great despotic model"(Wittfogel: 2000). In his comments about the Oriental societies he also adds that "a civilisation that once was part of this world (the Oriental one), can go on conserving in a later phase, some traces of its previous state, wich although are not necessary for the new configuration, they're compatible with it."'

After the collapse of the Ottoman Empire, Albania was in a chaotic identitarian situation after the verdict of the Congress of Berlin for dividing the country in several pieces. In this moment of confusion, after Prince Wied's arrival, a curious subversive character emerged accompanied with a group of peasants with the exclamation "dum' babën" (We want our father), refering to the Turkish rulership. This character, called Haxhi Qamili, with his peasants caused lots of riots during this period, but meanwhile his movement also proves the missing of some important symbolic figure at the top of the social edifice. His hate for christians ("the bad people, the christians, even god doesn't love them!")8 and his glorification towards the Islam and the Sultan shows the necessity of a central paternal authority that was inherited after a long time under conquest of Turkey. The absence of passed social rituals was reflected with acts of torture and violence of the movement of Haxhi Qamili towards the local christians, wich were accused from the former for "separating us from Turkey" (Arben Puto: 2011). This history shows the cultivation for worship towards the central authorities as a patrimonial figure, was present since the first years of Albanian independent state. All was left to do by the following rulers was just to fill up the ideological place prepared and cultivated during the Ottoman dominion with humiliating acts for the christians and unconditional bow downs for Albanian muslims. The movement of Qamili shows not only the social-ritualistic influences of the Ottoman rulership but mostly the modes of perception of the social community for the symbolic rituals that were constructed during the passed centuries. Furthermore, paternal conceptions like "father" can be frequently found in Enver Hoxha's regime too. This familliar conception was often used in people's self reference as "bij të Partisë" (sons of the party), sometimes arriving at extreme levels of glorification "edhe bar do të hamë nëse Partia na e kërkon" (we are ready to eat grass if the party demands for it). In this way, the symbolic acts of total submission learned under the Ottoman conquest were transformed and reproduced in a political matter under the despotic rule of Enver Hoxha. The whole image of the regime was constructed according to the parental figure in the middle of it. And what is the most important similarity between the two: Enver Hoxha just like the Ottoman Empire were seen as patrimonial figures that would protect Albanian people from the invasion of neighbour countries. For this reason, I think the most important part at this point is not the symbol as such but the ideological construction of it. As I said in the beginning of this work, society doesn't have a passive role in the construction of an ideology, but on the contrary, ideology is performed in a way that the society can identify itself with it. If the ideological myth doesn't fit the social structures of society then it's construction is almost impossible. Religion, law or culture are vain if there can't be found the social basis for their existence.

\section{The consolidation of Sultanistic rulership}

Several analysts of totalitarian societies have a very restraint knowledge of Albanian society, consequently they haven't included the Albanian despotic regime in any part of their categories of despotism. Linz \& Stepan in their work "Problems of democratic transition and consolidation" have classified the Albanian regime as semi-Authoritarian, concept wich leaves a great void in the analysis of Albanian society. If we look more closely, there can be found many similarities between the impact of Enver Hoxha's regime in Albania's social reality and that of turkish Empire. Just like the Ottoman Empire, Enver Hoxha's Communist Party monopolized the social rituals, wich ended with the total abolition of religion and it's substitution by the Labor Party's official faith. Enver Hoxha, also known as "the red Sultan"9 took power of all the

\footnotetext{
7 Wittfogel K, Despotizmi Oriental, Botime Toena, Tiranë 2000, p. 203

${ }^{8}$ Jelavich B, History of the Balkans: Twentieth century, The Press Syndicate of the University of Cambridge, UK 1999, p. 103

${ }^{9}$ Fischer B, Diktatoret e Ballkanit, AllS, Tirane 2008, f. 290
} 
social rituals of symbolic dominion. His national-communist ideology was extended from daily routine (obliged physical culture for everyone before going to work), till art, literature and national poems.

After a long time under conquest, all the social and religious rituals of the Ottoman Empire became an integral part of Albanian society; Literally, the entire social network of the politico-religious domination, became a system of reference for the society. In a certain way, this "Sultanistic regime" (As I called it somewhere else)10 gave the appropriate solution in isolating a social group under the panic of being divided or invaded once again. Since coming to power, the Communist nomenklatura started a bloody cleansing of all the potential rivals. These purges, with the passing of the years were followed by the construction of a personality cult by the dictator Hoxha wich continued with the abolition of religious monuments, practices and faith and the building of Enver Hoxha's monument in the center of Tirana right after his death. The interesting part was that near the monument of Hoxha was situated another great monument: that of Albanian's national hero "Skënderbeu" (Skanderbeg). All this ensemble of symbols took intact the collective imagination of the members of society wich - like under the Ottoman conquest - continued to stay symbolically under a great paternal figure. When the relations between Albania and the Soviet Union were solid, in the center of Tirana, instead of Skanderbeg there was the monument of the Communist leader Josip Stalin, who was symbolically perceived as "baba Stalini" (father Stalin). It's important to emphasize that right right after the Stalin's death, the ritual of total submission was performed again after a long time. Albanian people bowed again on their knees in front of Stalin's monument to show the divine dimensions of his figure. The continuity of the gesture of total submission is an important sign of the conservation of social practices from time to time, but also, it shows the political impact of manipulation to this practices just to keep awake the socio-symbolical imagination of the collectivity. The enormous monuments at the center of Tirana had a very important symbolical significance towards the social community: at a certain level they made all the citizens consciouss of their inferiority against State's faith :"The national myth" (personified by the symbol of Skanderbeg), and also against State's beloved missionary of this faith: Enver. Maybe this was the cause of the absence of a religious faith after 1967. Ultimately, the importance of religion is concentrated mainly in keeping intact and maintaining some order in a given social group through several ritualistic and religious practices. The Albanians used exactly with this purpose the convertion in Islam during the Ottoman period, although this choice made great transformations in the inner social rituals of society. It seems the adoption of Enver Hoxha's nationalist propaganda had exactly the same purpose. This process can be explained by the phrase of the national poet of the Renaissance Pashko Vasa: "feja e shqiptarit është shqiptaria" (the faith of Albanians is Albanianism). Albanian society adopted the nationalistic faith just like it did before with the Islamic faith. But this choice it looks that had it's side effects in acquiring an inferior position against the missionaries who propagandize these faiths. Albanian christians had to submit themselves to various acts of humuliation towards the muslims, similarly the converted muslims learned and adopted the ritual of total submission just like almost every member of the Oriental societies. An analogous fact happened in times of Hoxha's regime when people re-adopted their already learned ritual of total obedience, nonetheless this meant leaving behind all the principles of equality promoted during the years of the independece by the national poets of the Renaissance.

\section{Conclusions}

The performation of similar rituals from time to time doesn't show that the society haven't changed. On the contrary, it shows that the ideological instruments of domination have remained the same in society's perception. In this case, the figure of the ideological leader or missionary, still remains as a crucial point of reference and also a point when all the practices of respect, benevolence or submission are concentrated. The tradition of religious tolerance in Albanian society maybe hides an important fact: it's not very important of whom are adressed the performations of respect, submission or benevolence. Albania's national movements before the independece shaped the figure of a material god, whom wasn't above the people, but inside of them. It seems that this perception, shaped the future of Albania's political regimes where the absence of god in the center of their social being, constructed a powerful paternal figure inside the political dimension. This political god seems have dominated all Albanian history, but also it has conservated and inspirated a strong sense of unity among the members of society. 


\section{References}

Doja A, Bektashizmi në Shqipëri (Histori Politike e Një Lëvizjeje Fetare), AllS, Tiranë 2008

Fischer B, Diktatoret e Ballkanit, AllS, Tirane 2008

Hoxha L, Sulltanizmi në Shqipëri, UET, Tiranë 2009

Jelavich B, History of the Balkans: Twentieth century, The Press Syndicate of the University of Cambridge, UK 1999

Linz J \& Stepan A, Problems of democratic transition and consolidation, John Hopkins University Press, Baltimore, 1996

Ostrup J, Orientalische Hoflichkeit, Leipzig :O. Harrassowitz 1929

Thëngjilli P, Renta Feudale dhe Evoluimi i saj në Vise Shqiptare (Shek. XVII - mesi i shek. XVIII), Shtëpia Botuese e Librit Universitar, Tiranë 1990

Weber M, Economy \& Society: An Outline of Interpretive Sociology, Berkeley University of California Press, 1978

Wittfogel K, Despotizmi Oriental, Botime Toena, Tiranë 2000 